\title{
Why are heavy metal hyperaccumulating plants so amazing?
}

\author{
Ewa MuszyńsKa*, Ewa Hanus-FaJerska \\ Botany and Plant Physiology Unit, Institute of Plant Biology and Biotechnology, University of Agriculture in Krakow, Kraków, Poland
}

\begin{abstract}
In some areas, anthropogenic activity has led to a high level of environmental pollution with heavy metals that it is now detrimental to living organisms. However, there are about 500 plant species known to accumulate extraordinarily high amounts of metallic elements in their tissues without any noxious effect, and these plants, hyperaccumulators, have lately been receiving increasing interest, because of their potential for being exploited in sustainable biotechnologies such as phytoremediation and phytomining. This paper reviews on the basic mechanisms of tolerance enabling practical application of hyperaccumulating plants in the clean up of land contaminated with heavy metals.
\end{abstract}

Key words: heavy metal, hyperaccumulators, tolerance, phytoextraction, phytomining

\section{Introduction}

Widespread environmental pollution with heavy metals is mainly the consequence of certain anthropogenic activities such as mining, smelting, heavy traffic and railway transportation (Wiłkomirski et al., 2011; Candeias et al., 2015). It is quite well documented that an excessive amount of these metallic elements remains in the ecosystem for an extremely long time and poses a severe threat to organisms that are exposed to high levels of such pollutants. Among those organisms affected are plants whose essential physiological processes are frequently seriously impaired. In experiments conducted in worldwide laboratories it has been found that elevated concentrations of heavy metals exert a negative impact on processes such as respiration, photosynthesis, electron transport and cell division (Wójcik et al., 2009; Pourrut et al., 2011; Muszyńska et al., 2014b). Another well-documented effect of environmental pollution is uncontrolled production of reactive oxygen species that cause oxidative stress (Karuppanapandian et al., 2011; Biesiada and Tomczak, 2012; Hossain et al., 2012; Muszyńska et al., 2014a). The growth and development of plants may be considerably disturbed as a result of the negative influence of elevated levels of metals. However, there are plant species or specialized ecotypes that are able to tolerate high levels of trace elements and thus survive, grow and reproduce on soils contaminated with heavy metals. The majority of these species behave as "excluders" that retain and detoxify most of the heavy metals in their root tissues and minimize ion translocation to the shoots (Ghosh and Singh, 2005). This strategy has also been observed in populations of Armeria maritima, Plantago lanceolata, Silene vulgaris and Dianthus carthusianorum growing in Poland on metalliferous soils (Baranowska-Morek and Wierzbicka, 2004; SzarekŁukaszewska et al., 2004; Wierzbicka et al., 2004; Wójcik and Tukiendorf, 2014). Some other species, called "accumulators", exhibit contrasting behavior relying on active heavy metal uptake from the soil and then accumulation in organs. Among these accumulating plant species, the most interesting are so-called hyperaccumulators that can accumulate heavy metals in their above-ground organs at concentrations from 100 to 1000 -times higher than those found in non-hyperaccumulating species, without suffering any discernible phytotoxic effect (Jabeen et al., 2009; Grobelak et al., 2010; Rascio and Navari-Izzo, 2011).

\footnotetext{
* Corresponding author: Botany and Plant Physiology Unit, Institute of Plant Biology and Biotechnology, University of Agriculture in Krakow, Al. 29 Listopada 54, 31-425 Krakow, Poland; e-mail: emuszynska@ogr.ur.krakow.pl
} 


\section{Hyperaccumulating plants and basic mechanisms of accumulation}

Plants that accumulate metal and metalloid trace elements at extraordinarily high concentrations in their above-ground tissues are called "hyperaccumulators". This term was first used by Jaffré et al. (1976) and referred to Sebertia acuminata, in which Ni content accounted for $25 \%$ of the latex dry weight. A subsequent publication by Brooks et al. (1977) defined hyperaccumulators more precisely as plants with a Ni concentration in dried leaves above $0.1 \%$. Following these pioneering studies, Baker and Brooks (1989) extended the definition to include other metals, although with different thresholds (Table 1). Recently, van der Ent et al. (2013) recommended new criteria of hyperaccumulation, according to which the threshold concentration of metals should be 2-3 orders of magnitude higher than in leaves of most species growing on non-metalliferous soils, and at least one order of magnitude greater than the usual range found in plants from metalliferous soils (Table 1). A comparison of metal and metalloid contents in aerial organs required to classify the plant as a hyperaccumulator proposed by both groups of authors is given in Table 1.

Table 1. Metal concentrations in dried foliage $\left[\mathrm{mg} \cdot \mathrm{kg}^{-1} \mathrm{~d} . \mathrm{m}\right.$.] according to different authors' criteria

\begin{tabular}{l|c|c}
\hline Heavy metal & $\begin{array}{c}\text { Baker and Brooks } \\
(1989)\end{array}$ & $\begin{array}{c}\text { van der Ent } \\
(2013)\end{array}$ \\
\hline $\mathrm{Cd}$ & 100 & 100 \\
\hline $\mathrm{Co}, \mathrm{Cu}, \mathrm{Cr}$ & 1000 & 300 \\
\hline $\mathrm{Pb}, \mathrm{Ni}$ & 1000 & 1000 \\
\hline $\mathrm{Zn}$ & 10000 & 3000 \\
\hline $\mathrm{Mn}$ & 10000 & 10000 \\
\hline
\end{tabular}

Based on the criteria suggested by van der Ent (2013), approximately 500 taxa have been identified so far as hyperaccumulators of one or more metals. Thus, hyperaccumulation is a rare phenomenon characteristic of less than $0.2 \%$ of all known angiosperms (Pollard et al., 2014). The most common are representatives of the following families: Brassicaceae, Caryophylaceae, Violaceae, Fabaceae, Euphorbiaceae, Lamiaceae, Asteraceae, Cyperaceae, Poaceae, Cunouniaceae, Flacourtiaceae. Some examples of important hyperaccumulators are presented in Table 2.
Hyperaccumulation depends on three main traits that distinguish hyperaccumulators from non-hyperaccumulating plants: 1) a much greater capacity to take up heavy metals from the soil; 2) enhanced root-to-shoot translocation of metal ions; 3 ) a much greater ability to detoxify and sequester extremely large amounts of heavy metals in the shoots (Rascio and Navari-Izzo, 2011). An important aspect of the heavy metal uptake by plants is the bioavailability of toxic ions in the soil. In this regard, three categories of heavy metals/metalloids can be distinguished: readily bioavailable $(\mathrm{Cd}, \mathrm{Ni}, \mathrm{Zn}, \mathrm{As}$, Se, $\mathrm{Cu}$ ); moderately bioavailable (Co, $\mathrm{Mn}$ ) and least bioavailable ( $\mathrm{Pb}, \mathrm{Cr}$ ) (Ali et al. 2013). However, in the rhizosphere of hyperaccumulators, metal availability is reported to be higher than in non-hyperaccumulating plants, because the former have developed certain mechanisms for solubilizing heavy metals in the soil (Maestri et al., 2010). Some hyperaccumulators release protons or specific root exudates such as organic acids (mugenic or aveic acids) and phytosiderophores that acidify the rhizosphere and thus increase metal mobilization from the soil (Maestri et al., 2010; Rajkumar et al., 2012). Furthermore, the bioavailability of heavy metals may be significantly increased by the rhizosphere microorganism community (mainly bacteria and mycorrhizal fungi) that can affect metal mobility in many ways, including lowering the $\mathrm{pH}$, producing compounds such as antibiotics, organic acids, and hormones, and enhancing plant shoots and root biomass (Jabeen et al., 2009).

When bioavailable metals come into contact with under-ground parts of plants, they penetrate into the root, mainly through the same transporters located in the plasma membrane that are involved in the uptake of macro- and microelements. For example, there is strong evidence that As can enter plant roots as arsenate via the transporters of the chemical analogue phosphate, which comes from the fact that a higher density of phosphate/arsenate transporters has been observed in root cells of As hyperaccumulator Pteris vittata than nonhyperaccumulator Populus tremula (Caille et al., 2005). Additionally, to regulate the metal concentration within the root as well as shoot cells, several classes of metal transporters located in the plasma membrane and the tonoplast have been identified. Among these, the zinc/iron permeases (ZIP), the heavy metal (or CPXtype) ATPases, the natural resistance associated macrophage-proteins (Nramp), the cation exchangers (CAXs) 
Table 2. Examples of hyperaccumulating plant species belonging to different families

\begin{tabular}{|c|c|c|c|}
\hline Family & Species & Heavy metal & References \\
\hline Asteraceae & Berkheya coddii & $\mathrm{Ni}$ & $\begin{array}{l}\text { Mesjasz-Przybyłowicz et al. 2004; } \\
\text { Orłowska et al. } 2011\end{array}$ \\
\hline Brassicaceae & Alyssum bertolonii & $\mathrm{Ni}$ & $\begin{array}{l}\text { Galardi et al. 2007; } \\
\text { Mengoni et al. } 2012\end{array}$ \\
\hline Brassicaceae & Alyssum markgrafii & $\mathrm{Ni}$ & Bani et al. 2010 \\
\hline Brassicaceae & Alyssum murale & $\mathrm{Ni}$ & $\begin{array}{l}\text { Bani et al. 2010; } \\
\text { Lucisine et al. } 2014\end{array}$ \\
\hline Brassicaceae & Arabidopsis halleri & $\begin{array}{l}\mathrm{Zn} \\
\mathrm{Cd}\end{array}$ & $\begin{array}{l}\text { Maestri et al. 2010; } \\
\text { Huguet et al. 2012; } \\
\text { Verbruggen et al. } 2013\end{array}$ \\
\hline Brassicaceae & Biscutella laevigata & $\mathrm{Tl}$ & $\begin{array}{l}\text { Pošćić et al. 2013; } \\
\text { Babst-Kostecka et al. } 2014\end{array}$ \\
\hline Caryophyllaceae & Minuartia verna & $\mathrm{Pb}$ & Maestri et al. 2010 \\
\hline Crassulaceae & Sedum alfredii & $\mathrm{Pb}$ & $\begin{array}{l}\text { Tian et al. } 2010 \\
\text { Lu et al. } 2013\end{array}$ \\
\hline Fabaceae & Astragalus racemosus & Se & $\begin{array}{l}\text { Galeas et al. } 2007 ; \\
\text { Lindblom et al. } 2013\end{array}$ \\
\hline Lamiaceae & Haumaniastrum katangense & $\begin{array}{l}\mathrm{Cu} \\
\mathrm{Co}\end{array}$ & Brooks 1977 \\
\hline Myrthaceae & Gossia bidwillii & $\mathrm{Mn}$ & Fernando et al. 2007 \\
\hline Plumbaginaceae & Armeria maritima ssp. halleri & $\begin{array}{l}\mathrm{Zn}, \\
\mathrm{Pb}\end{array}$ & $\begin{array}{l}\text { Ciarkowska and Hanus-Fajerska 2008; } \\
\text { Abratowska et al. } 2012\end{array}$ \\
\hline Poaceae & Spartina argentinensis & $\mathrm{Cr}$ & Redondo-Gomez et al. 2011 \\
\hline Pteridaceae & Pteris vittata & As & $\begin{array}{l}\text { Wu et al. } 2009 ; \\
\text { Wan et al. } 2014\end{array}$ \\
\hline Violaceae & Viola boashanensis & $\mathrm{Cd}$ & $\begin{array}{l}\text { Liu et al. } 2004 ; \\
\text { Wu et al. } 2010\end{array}$ \\
\hline
\end{tabular}

or the cation-diffusion facilitator (CDF) could be listed (Rascio and Navari-Izzo, 2011).

In contrast to non-hyperaccumulator plants which retain most of the heavy metals taken up from the soil in their root cells, hyperaccumulators rapidly and efficiently translocate these elements to the shoot via the xylem. The root-to-shoot translocation depends on the different low molecular weight chelators that bind to metal ions and transpiration pulls these complexes up to the leaves (Jabeen et al., 2009). The most important in this process seem to be free amino acids, such as histidine and nicotinamine, which form stable complexes with bivalent cations (Rascio and Navari-Izzo, 2011).

An important role in hyperaccumulation is played by the mechanisms of detoxification and sequestration of heavy metals which allow significant amounts of these toxic ions to be concentrated in aerial plant organs without causing any phytotoxic effect. Detoxification and sequestration is based on metal complexation with ligands and/or their removal from metabolically active cytoplasm (Jabeen et al., 2009; Bhargava et al., 2012; Wójcik and Tukiendorf, 2014). There are two main types of peptide metal binding ligands - phytochelatins and metallothioneins. These are Cys-rich polypeptides binding heavy metals via the thiol groups of their Cys residues (Hossain et al., 2012). Besides these, many other small molecules are used in the metal chelation inside the cytosol. Potential ligands for heavy metals can also be organic and amino acids, such as citrate, malate, and oxalate acids (Maestri et al., 2010). Such ligands may be instrumental in preventing the persistence of heavy metals as free ions in the cytoplasm and in moving them into in- 
active compartments, mainly vacuoles, cell walls or dictyosomes (Tangahu et al., 2011; Bhargava et al., 2012). For instance, it has been found that malate is the main ligand of $\mathrm{Cd}^{2+}$ in Noccaea (Thlaspi) caerulescens, while citrate and acetate bind this metal in leaves of Solanum nigrum (Salt et al., 1999; Sun et al., 2006). Sequestration of excess metal ions can occur in the vacuoles of leaf mesophyll and epidermis, the trichomes, the cuticule, and the secretory glands or in the form of salt crystals on the surface of salt glands. This type of secretion has been observed, for example, in many Alyssum species (Alyssum murale, Alyssum corsicum, Alyssum pterocarpum), Armeria maritima ssp. halleri, Arabidopsis halleri and Noccaea caerulescens (Broadhurst et al., 2004; Küpper et al., 2004; Eapen and D'Souza, 2005; Wójcik et al., 2005; Abratowska, 2006; Huguet et al., 2012).

\section{Practical applications of plants with accumulation traits}

The concentration of toxic elements in the environment has been increasing year by year. Therefore, research is still needed to develop cost effective, efficient and environmentally friendly remediation methods for the decontamination of heavy metal-polluted soils. A novel approach is phytoremediation, which is considered a green alternative to the problem of heavy metal contamination (Greipsson, 2011; Ali et al., 2013). Phytoremediation refers to the use of plants and associated soil microbes to remove harmful substances such as heavy metals, radionuclides and organic pollutants from the environment or to decrease their toxicity (Greipsson, 2011; Tangahu et al., 2011). For this reason, plant species that can absorb, detoxify and store high levels of heavy metals attract particular interest due to the possibility of exploiting their accumulation traits in practical applications for cleaning up soils contaminated with heavy metals. Thus, hyperaccumulating plants can be used in phytoextraction. An ideal hypothetical plant for this strategy should have multiple traits, such as the ability to accumulate large amounts of heavy metals (bioconcentration factor more than 1), rapid growth, and large biomass production (at least 10 tons per hectare, since the rate of phytoextraction is directly proportional to the plant growth rate while the total amount of metal phytoextracted is correlated with the plant biomass) (Shah and Nongkynrih, 2007; Ali et al., 2013). One of the best-known angiosperm hyperaccumulators of metals is
Noccaea caerulescens, which can accumulate large amounts of $\mathrm{Zn}\left(39600 \mathrm{mg} \cdot \mathrm{kg}^{-1}\right)$ and $\mathrm{Cd}\left(1800 \mathrm{mg} \cdot \mathrm{kg}^{-1}\right)$ without apparent damage (Rascio and Navari-Izzo, 2011; Bhagrava et al., 2012). However, N. caerulescens as well as many other hyperaccumulators have a relatively limited potential for effective phytoextraction, because most of them are characterized by rather shallow root systems, slow growth rates and, in consequence, they usually produce low biomass in each successive year. Moreover, hyperracumulating plant species are metal selective. No species has been found which accumulates all elements of interest, which complicates the matter as much as the limit imposed by the speed of metal removal (Shah and Nongkynrih, 2007; Bhargava et al., 2012). A possible good candidate for phytoextraction is Brassica juncea that accumulates lead, cadmium, chromium, nickel and zinc. Above all, this species is characterized by high biomass production ( 8 tons/ha in two months), easy adaptation to growth in different climatic conditions and a deep root system helpful for efficient metal absorption and prevention of those toxic elements entering into the groundwater (Bhargava et al., 2012; Satpathy and Reddy, 2013).

Not only is the proper selection of plant material important for a successful and economically feasible phytoextraction process: it is also advisable to stimulate metal bioavailability in the rhizosphere. Apart from the natural mechanisms that enhance the availability of ions for uptake by plants, the addition of synthetic chelators can stimulate the release of metals into soil solutions, and therefore improve their mobility and accumulation in plant tissues. Several chelating agents such as EDTA, CDTA, DTPA, EGTA or NTA have been successfully used to remediate heavy metal contaminated soils (Seuntjens et al., 2004; Rajkumar et al., 2012). At the end of the growing season, plants with accumulated toxic substances in their organs are collected from the purified surface with the use of conventional equipment. Next, harvested biomass containing heavy metals can be combusted to obtain energy. The remaining ash is considered a "bio-ore" that is used for the extraction of heavy metals (Jabeen et al., 2009; Ali et al., 2013). Phytomining has been commercially used for $\mathrm{Ni}$ extraction and it is believed to be less expensive than conventional methods. For example, cultivation of $A$. murale and $A$. corsicum enables biomass containing $400 \mathrm{~kg}$ Ni per hectare to be obtained with low production costs (about 250- 
500 USD/ha). Considering the Ni price (40 USD/kg), phytomining of this element has become a highly profitable technology that can provide about 10 00020000 USD per ha (Chaney et al. 2007). This technology can also be successfully recommended for ores, the mining of which using traditional methods is unprofitable (Bhargava et al., 2012). In addition, phytomining is a more eco-friendly option in comparison with conventional extraction techniques. This is because during bio-ore processing renewable energy is generated and less $\mathrm{SO}_{x}$ is emitted to the atmosphere (Ali et al., 2013). A new trend in the usage of harvested biomass from hyperaccumulators is the preparation of "eco-catalysts" (Escande et al., 2014; Escande et al., 2015). After the thermal treatment of plant material with accumulated heavy metals and then its subjection to acidic workup, a polymetallic solid that could serve as a catalyst for various chemical transformations is obtained. Thus, the application of hyperaccumulating plants for catalyst production is a novel, interesting and innovative approach.

\section{Conclusions}

Although metal hyperaccumulating plants are a promising material for the removal of heavy metals from contaminated soils, there are some limitations to the application of phytoextraction. One is the long period of time required for clean-up. Moreover, there is a limited number of plant species that are effective hyperaccumulators, and thus a limited number of trace elements that can be extracted this way. The extraction efficiency of most plants is additionally limited by their shallow root system, slow growth rate and consequently low biomass production. Metals can also be strongly bound to soil particles and thus are very slightly soluble in soil solution and not easily taken up by plants (Grobelak et al., 2010; Tangahu et al., 2011; Ali et al., 2013). In view of the current ecological trends, special attention is paid to species with the ability to accumulate extremely large amounts of heavy metals in their tissues. It is believed that new research will result in the discovery of many new metal hyperaccumulating species. In order to further exploit the potential of currently identified metal accumulating plants, a comprehensive understanding of soil-metal-organism interactions is urgently needed. However, in order to undertake high performance phytoremediation projects, specialist knowledge of soil che- mistry, microbiota, hyperacumulator plant biology and ecology must first be broadened.

\section{References}

Abratowska A. (2006) Armeria maritima - gatunek roślin przystosowany do wzrostu na glebach skażonych metalami ciężkimi. Kosmos - Probl. Nauk Biol. 55: 217-227.

Abratowska A., Wąsowicz P., Bednarek P.T., Telka J., Wierzbicka M. (2012) Morphological and genetic distinctiveness of metallicolous and non-metalicolous populations of Armeria maritima s.l. (Plumbaginaceae) in Poland. Plant Biol. 14(4): 585-595.

Ali H., Khan E., Sajad M.A. (2013) Phytoremediation of heavy metals - concepts and applications. Chemosphere 91: 869-881.

Babst-Kostecka A., Parisod Ch., Godé C., Vollenveider P., Pauwels M. (2014) Patterns of genetic divergence among populations of the pseudometallophyte Biscutella laevigata from southern Poland. Plant Soil 383: 245-256.

Baker A.J.M., Brooks R.R. (1989) Terrestial higher plants which hyperaccumulate metallic elements. A review of their distribution, ecology and phytochemistry. Biorecovery $1: 81-126$.

Bani A., Pavlova D., Guillaume Echevarria G., Mullaj A., Reeves R.D., Morel J. L., Sulçe S. (2010) Nickel hyperaccumulation by the species of Alyssum and Thlaspi (Brassicaceae) from the ultramafic soils of the Balkans. Bot. Serbica 34(1): 3-14.

Baranowska-Morek A., Wierzbicka M. (2004) Localization of lead in root tip of Dianthus carthusianorum. Acta Biol. Cracov. Ser. Bot. 46: 45-56.

Bhargava A., Carmona F.F., Bhargava M., Srivastava S. (2012) Approaches for enhanced phytoextraction of heavy metals. J. Environ. Manag. 105: 103-120.

Biesiada A., Tomczak A. (2012) Biotic and abiotic factors affecting the content of the chosen antioxidant compounds in vegetables. Veget. Crops Res. Bull. 76: 55-78.

Broadhurst C., Tappero R., Maugel T., Erbe E., Sparks D., Chaney R. (2004) Interaction of nickel and manganese in accumulation and localization in leaves of Ni hyperaccumulators Alyssum murale and Alyssum corsicum. Plant Soil 314: 35-48.

Brooks R.R. (1977) Copper and cobalt uptake by Haumaniastrum species. Plant Soil 48: 541-544.

Brooks R.R., Lee J., Reeves R.D., Jaffré T. (1977) Detection of nickliferous rocks by analysis of herbarium specimens of indicator plants. J. Geochem. Explor. 7: 49-57.

Candeias C., Ávila P.F., da Silva E.F., Ferreira A., Durães N., Teixeira J.P. (2015) Water-Rock interaction and geochemical processes in surface waters influenced by tailings impoundments: impact and threads to the ecosystems and human health in rural communities (Panasquiera Mine, Central Portugal). Water Air Soil Pollut. 226: 1-23.

Caille N., Zhao F.J., McGrath S.P. (2005) Comparison of root absorption, translocation and tolerance of arsenic in the 
hyperaccumulator Pteris vittata and the non-hyperaccumulator Pteris tremula. New Phytol. 165: 755-761.

Chaney R.L., Angle J.S., Broadhurst C.L., Peters C.A., Tappero R.V., Sparks D.L. (2007) Improved understanding of hyperaccumulation yields commercial phytoextraction and phytomining technologies. J. Environ. Quality 36: 1429-1443.

Ciarkowska K., Hanus-Fajerska E. (2008) Remediation of soilfree grounds contaminated by zinc, lead and cadmium with the use of metallophytes. Pol. J. Environ. Stud. 17(5): 707-712.

Eapen S., D'Souza S.F. (2005) Prospects of genetic engineering plants for phytoremediation of toxic metals. Biotechnol. Adv. 23: 94-114.

Escande V., Olszewski T.K., Grison C. (2015) From biodiversity to catalytic diversity: how to control the reaction mechanism by the nature of metallophytes. Environ. Sci. Pollut. Res. 22: 5653-5666.

Escande V., Olszewski T. K., Grison C. (2014) Preparation of ecological catalysts derived from $Z n$ hyperaccumulating plants and their catalytic activity in Diels-Alder reaction. Compt. Rend. Chimie 17: 731-737.

Fernando D.R., Woodrow I.E., Bakkaus E.J., Collins R.N., Baker A.J.M., Batianoff G.N. (2007) Variability of $M n$ hyperaccumulation in the Australian rainforest tree Gossia bidwillii (Myrtaceae). Plant Soil 293: 145-152.

Galardi F., Mengoni A., Pucci S., Barletti L., Massi L., Barzanti R., Gabbrielli R., Gonnelli C. (2007) Intra-specific differences in mineral element composition in the $\mathrm{Ni}$ hyperaccumulator Alyssum bertolonii: A survey of populations in nature. Environ. Exp. Bot. 60: 50-56.

Galeas M.L., Zhang L.H., Freeman J.L., Wegner M., PilonSmits E.A.H. (2007) Seasonal fluctuations of selenium and sulfur accumulation in selenium hyperaccumulators and related nonaccumulators. New Phytol. 173: 517-525.

Ghosh M., Singh S.P. (2005) A review on phytoremediation of heavy metals and utilization of its byproducts. Appl. Ecol. Environ. Res. 3(1): 1-18.

Greipsson S. (2011) Phytoremediation. Nat. Edu. Knowl. 2: 7.

Grobelak A., Kacprzak M., Fijałkowski K. (2010) Phytoremediation - the underestimated potential of plants in cleaning up environment. J. Ecol. Health 14(6): 276-280.

Hossain M. A., Piyatida P., Teixeira da Silva T. A., Fujita M. (2012) Molecular mechanism of heavy metal toxicity and tolerance in plants: central role of glutathione in detoxification of reactive oxygen species and methylglyoxal and in heavy metal chelation. J. Botany 2012: 1-37.

Huguet S., Bert V., Laboudigue A., Barthes V., Isaure M.-P., Llorens I., Schat H., Sarret G. (2012) Cd speciation and localization in the hyperaccumulator Arabidopsis halleri. Environ. Exp. Bot. 82: 54-65.

Jabeen R., Ahmad A., Iqbal M. (2009) Phytoremediation of heavy metals: physiological and molecular mechanisms. Bot. Rev. 75: 339-364.

Jaffré T., Brooks R.R., Lee J., Reeves R.D. (1976) Sebertia acuminata - A Hyperaccumulator of nickel from $\mathrm{NeW}$ Caledonia. Science 193: 579-580.
Karuppanapandian T., Moon J.-C., Kim C., Manoharan K., Kim W. (2011) Reactive oxygen species in plants: their generation, signal transduction, and scavenging mechanisms. Austral. J. Crop Sci. 5(6): 709-725.

Küpper H., Mijovilovich A., Meyer-Klaucke W., Kroneck P.M.H. (2004) Tissue and age-dependent differences in the complexation of cadmium and zinc in the cadmium/zinc hyperaccumulator Thlaspi caerulescens (Ganges ecotype) revealed by X-Ray absorption spectroscopy. Plant Physiol. 134: 748-757.

Lindblom S.D., Fakra S.C., Landon J., Schultz P., Tracy B., Pilon-Smits E.A.H. (2013) Inoculation of Astragalus racemosus and Astragalus convallarius withselenium-hyperaccumulator rizosphere fungi affects growth and selenium accumulation. Planta 237: 717-729.

Liu W., Shu W.S., Lan C.Y. (2004) Viola boashanensis a plant that hyperaccumulates cadmium. Chin. Sci. Bull. 49: 29-34.

Lu L., Tian S., Zhang J., Yang X., Labavitch J.M., Webb S.M., Latimer M., Brown P.H. (2013) Efficient xylem transport and phloem remobilization of $Z n$ in the hyperaccumulator plant species Sedum alfredii. New Phytol. 198: 721-731.

Lucisine P., Echevarria G., Sterckeman T., Vallance J., Rey P., Benizri E. (2014) Effect of hyperaccumulating plant cover composition and rizosphere-associated bacteria on the efficiency of nickel extraction from soil. Appl. Soil Ecol. 81: 30-36.

Maestri H., Marmiroli M., Visoli G., Marmiroli N. (2010) Metal tolerance and hyperaccumulation. Costs and tradeoffs between traits and environment. Environ. Exp. Bot. 68: $1-13$.

Mengoni A., Cecchi L., Gonelli K. (2012) Nickel hyperaccumulating plants and Alyssum bertolonii: model systems for studying biogeochemical interactions in sepentine soils. In: Bio-Geo Interactions in Metal Contaminated Soils. Soil Biology. Eds. Kothe E., Varma A., p. 279-296.

Mesjasz-Przybyłowicz J., Nakonieczny M., Migula P., Augustyniak M., Tarnawska M., Reimold W.U., Koeberl C., Przybyłowicz W., Głowacka E. (2004) Uptake of cadmium, lead, nickel and zinc from soil and water solutions by the nickel hyperaccumulator Berkheya coddii. Acta Biol. Cracov. Ser. Bot. 46: 75-85.

Muszyńska E., Kałużny K., Hanus-Fajerska E. (2014a) Phenolic compounds in Hippophae rhamnoides leaves collected from heavy metal contaminated. Plants Urban Areas Landsc. 11-15.

Muszyńska E., Piwowarczyk B., Kałużny K., Koźminska A. (2014b) Evaluation of the usefulness of sea buckthorn for planting in various urban areas according to photosynthetic apparatus efficiency and antioxidant activity. Logistyka 4(6): 4717-4723.

Nagajyoti P.C., Lee K.D., Sreekanth T.V.M. (2010) Heavy metals, occurrence and toxicity for plants: a review. Environ. Chem. Lett. 8: 199-216.

Orłowska E., Przybyłowicz W., Orlowski D., Turnau K., Mesjasz-Przybyłowicz J. (2011) The effect of mycorrhiza on 
growth and elemental composition of Ni-hyperaccumulating plant Berkheya coddii Roessler. Environ. Pollution 159: 3730-3738.

Pollard A.J., Reeves R.D., Baker A.J.M. (2014) Facultative hyperaccumulation of heavy metals and metalloids. Plant Sci. 217-218: 8-17.

Pošćić F., Marchiol L., Schat H. (2013) Hyperaccumulation of thallium is population-specific and uncorrelated with caesium accumulation in the thallium hyperaccumulator, Biscutella laevigata. Plant Soil 365: 81-91.

Pourrut B., Shahid M., Dumat C., Winterton P., Pinelli E. (2011) Lead uptake, toxicity, and detoxification in plants. Rev. Environ. Contamin. Toxicol. 213: 113-136.

Rajkumar M., Sandhya S., Prasad M.N.V., Freitas H. (2012) Perspectives of plant-associated microbes in heavy metal phytoremediation. Biotech. Adv. 30: 1562-1574.

Rascio N., Navari-Izzo F. (2011) Heavy metal hyperaccumulating plants: How and why do they do it? And what makes them so interesting? Plant Sci. 180: 169-181.

Salt D., Prince R., Baker A.J.M., Raskin J., Pickering I. (1999) Zinc ligands in the metal hyperaccumulator Thlaspicaerulescens as determined using $X$-ray absorption spectroscopy. Environ. Sci. Technol. 33: 713-717.

Satpathy D., Reddy M.V. (2013) Phytoextraction of $C d, P b$, $\mathrm{Zn}, \mathrm{Cu}$ and $\mathrm{Mn}$ by Indian mustard (Brassica juncea L.) grown on loamy soil amended with heavy metal contaminated municipal solid waste compost. Appl. Ecol. Environ. Res. 11(4): 661-679.

Seuntjens P., Nowack B., Schulin R. (2004) Root-zone modeling of heavy metal uptake and leaching in the presence of organic ligands. Plant Soil 265(1-2): 61-73.

Shah K., Nongkynrih J.M. (2007) Metal hyperaccumulation and bioremediation. Biol. Plant. 51(4): 618-634.

Sun R.-L., Zhou Q.-X., Sun F.-H., Jin C.-X. (2006) Antioxidative defense and proline/phytochelatin accumulation in a newly discovered Cd-hyperaccumulator, Solanum nigrum L. Environ. Exp. Bot. 60: 468-476.

Szarek-Łukaszewska G., Słysz A., Wierzbicka M. (2004) Response of Armeria maritima (Mill.) Willd. to $C d, Z n$ and $P b$. Acta Biol. Cracov. Ser. Bot. 46: 19-24.

Tangahu B.V., Abdullah S.R.S., Basri H., Idris M., Anuar N., Mukhlisin M. (2011) A review on heavy metals (As, $P b$, and $\mathrm{Hg}$ ) uptake by plants through phytoremediation. Int. J. Chem. Eng. 2011: 1-31.
Tian S.K., Lu L.L., Yang X.E., Webb S.M., Du Y.H., Brown P.H. (2010) Spatial imaging and speciation of lead in the accumulator plant Sedum alfredii by microscopically focused synchrotron X-ray investigation. Environ. Sci. Technol. 44: 5920-5926.

Van der Ent A., Baker A.J.M., Reeves R.D., Pollard A.J., Schat H. (2013) Hyperaccumulators of metal and metalloid trace elements: Facts and fiction. Plant Soil 362: 319-334.

Verbruggen N., Juraniec M., Baliardini C., Meyer C.L. (2013) Tolerance to cadmium in plants: the special case of hyperaccumulators. Biometals 26: 633-638.

Wan X., Lei M., Chen T., Zhou G., Yang J., Zhou X., Zhang X., $\mathrm{Xu}$ R. (2014) Phytoremediation potential of Pterris vittata $L$. under the combined contamination of $A$ s and $P b$ : beneficial interactions between $A$ s and $P b$. Environ. Sci. Pollut. Res. 21: 325-336.

Wierzbicka M., Szarek-Łukaszewska G., Grodzińska K. (2004) Highly toxic thallium in plants from the vicinity of Olkusz (Poland). Ecotoxicol. Environ. Safety 59: 84-88.

Wiłkomirski B., Sudnik-Wójcikowska B., Galera H., Wierzbicka M., Malawska M. (2011) Railway transportation as serious source of organic and inorganic pollution. Water Air Soil Pollut. 218: 333-345.

Wójcik M., Pawlikowska-Pawlęga B., Tukiendorf A. (2009) Physiological and ultrastructural changes in Arabidopsis thaliana as affected by changed GSH Level and $C u$ Excess. Russ. J. Plant Physiol. 56(6): 820-829.

Wójcik M., Tukiendorf A. (2014) Accumulation and tolerance of lead in two contrasting ecotypes of Dianthus carthusianorum. Phytochemistry 100: 60-65.

Wójcik M., Vangronsveld J., D’Haen J., Tukiendorf A. (2005) Cadmium tolerance in Thlaspi caerulescens II. Localization of cadmium in Thlaspi caerulescens. Environ. Exp. Bot. 53: 163-171.

Wu C., Liao B., Wang S.L., Zhang J., Li T.J. (2010) $P b$ and $Z n$ accumulation in Cd-hyperaccumulator (Viola boashanensis). Int. J. Phytoremed. 12(6): 574-585.

Wu F.Y., Leung H.M., Wu S.C., Ye Z.H., Wong M.H. (2009) Variation in arsenic, lead and zinc tolerance and accumulation in six populations of Pteris vittata L. from China. Environ. Pollut. 157: 2394-2404. 